\title{
COMPARISON OF EXPERIMENTAL COMPETITIVE-EXCLUSION CULTURES FOR CONTROLLING SALMONELLA COLONIZATION IN BROILER CHICKS
}

\author{
Liliana Revolledo; Claudete Serrano Astolfi Ferreira; Antonio José Piantino Ferreira*
}

Departamento de Patologia, Faculdade de Medicina Veterinária e Zootecnia, Universidade de São Paulo, São Paulo, SP, Brasil.

Submitted: February 24, 2003; Returned to Authors for corrections: July 25, 2003; Approved: December 12, 2003

\begin{abstract}
The efficacy of three different types of experimental competitive exclusion (CE-A, CE-B and CE-C) cultures against Salmonella Kedougou (SK) NCTC 12173, resistant to nalidixic-acid resistant $\left(\mathrm{Nal}^{\mathrm{R}}\right)$, in one-day-old broiler chicks, in four treatments with three replicates in each treatment, was evaluated. The mean logarithmic counts of Salmonella program of feces were $0.4 \mathrm{~L}$ in the group treated with CE-A, derived from the whole cecal contents of an adult bird with a mixture of aerobic and anaerobic bacterial cultures; 1.22 in the group treated with CE-B, containing aerobic bacterial culture; 1.00 in the group treated with $\mathrm{CE}-\mathrm{C}$, containing anaerobic bacterial culture; and 6.64 in the control group. The percentage of colonized birds varied from $10 \%$ to $26.66 \%$ in the treated groups and was $63.33 \%$ in the control group. A good protection (76.66\% to $90 \%$ ) was obtained in all treatments whereas lower protection was verified with experimental products containing only aerobic or anaerobic cultures. These results showed that a mixture of aerobic and anaerobic cultures can be effective for reducing SK colonization in broiler chicks.
\end{abstract}

Key words: Competitive exclusion, Salmonella, broiler chicks.

\section{INTRODUCTION}

Salmonella infections are mainly assymptomatic in poultry, but are associated with widespread human illness from this source. Therefore, there is continuing interest in finding ways of preventing flock infection and hence contamination of poultry products with Salmonella (24).

The work of Nurmi and Rantala (22) highlighted the link between susceptibility to Salmonella infection and the delayed development of the microbiota in the gastro-intestinal (GI) tract of young chickens. It also provided a simple, practical solution to the problem through the early establishment of an adult-type microflora that markedly increased the resistance of the bird to Salmonella colonization. The protective effect depends upon the administration of viable bacteria that must include certain obligate anaerobes.

Treated flocks can be expected to have fewer Salmonellapositive birds than untreated controls and lower levels of cecal colonization in those birds that become infected (20).
The complexity of the protective microbiota appears to be important. Attempts to use simpler defined mixtures of treatment bacteria, including conventional probiotic preparations, have been less successful (32).

Several commercial competitive exclusion $(\mathrm{CE})$ products have become available $(14,20)$ and these are based on anaerobic cultures of cecal material from suitable adult donor birds that have been extensively screened to ensure the absence of avian and human pathogens. The products are of undefined composition, but most have been partly characterised and are known to include the principal organisms that occur naturally in the ceca of adult chickens. Products aimed at protecting chickens against Salmonella colonization may also be used for turkeys, since there is reciprocal protection between the two $(1,29)$.

As an intervention measure, $C E$ treatment is of particular value in controlling horizontal transmission of Salmonella among chicks. For optimum efficacy, however, chicks need to be free from Salmonella prior to treatment and reared under conditions of good biosecurity, especially during the first two days following

*Corresponding author: Mailing Address. Departamento de Patologia, Faculdade de Medicina Veterinária e Zootecnia, Universidade de São Paulo. Av. Prof Orlando Marques de Paiva 87. 05508-000, São Paulo, SP Brasil. Tel.: (+5511) 3091-7706. Fax: (+5511) 3091-7829. E-mail: ajpferr@usp.br 
treatment when the administered organisms are becoming established. Advantages of the treatment include the ease of application (usually by spray-inoculation in the hatchery) and the protection provided against any salmonellas capable of invading the GI tract (20). The response to treatment is relatively rapid and there appears to be full compatibility with other intervention measures such as vaccination and treatment of feed with organic acids. CE treatment is particularly appropriate for the broiler, where any period of Salmonella shedding leads to external contamination of the bird and subsequent spread of the organisms among processed carcasses.

This study was initiated to determine the efficacy and protective effect of experimental $\mathrm{CE}$ cultures to reduce Salmonella spp. in broiler chicks.

\section{MATERIALSAND METHODS}

\section{Experimental animals}

Trials were carried out on newly hatched male chicks (Ross) obtained directly from an industrial hatchery. Chicks were housed in boxes, $1.70 \mathrm{~m}^{2}$. Chicks were reared on new wood shaves litter in floor-pens. In each trial, 30 randomly selected chicks were placed in each pen. Temperatures were at least $29^{\circ} \mathrm{C}$ under brooder lamps in each box. Non chlorinated water was used, feed was commercially prepared non-medicated broiler starter crumbles.

\section{Challenge organism}

Salmonella Kedougou (SK) strain NCTC 12173 nalidixicacid resistant $\left(\mathrm{Nal}^{\mathrm{R}}\right)$ at the final concentration $20 \mu \mathrm{g} / \mathrm{mL}$, originally isolated from chickens, being non-pathogenic for humans, noninvasive in chicks but able to colonise the ceca, was used for the infective treatment (21).

\section{Preparation of CE cultures}

Three cecal cultures were prepared from cecal content of adult Salmonella-free donor hen. The cecum was aseptically removed from the adult chicken and it was placed in a sterile petri dish. Then, the dull edge of a sterile scalpel blade was used to gently remove adherent cecal contents. Next the epithelium was scraped, and a sterile syringe was used to collect the rinsate from the petri dish. The cultures were prepared by inoculating $1.0 \mathrm{~g}$ of fresh cecal content and epithelium into three bottle contents $1 \mathrm{~L}$ of $\mathrm{BHI}$ (Brain heart infusion broth) supplemented with $0.5 \%$ cysteine- $\mathrm{HCl}$, according with Bailey et al. (3) and Blankenship et al. (6). In order to obtain CE-B, the bottle was incubated at $37^{\circ} \mathrm{C}$ for $24 \mathrm{~h}$ using a shaker (100 rpm) under aerobic conditions. The anaerobic bacterial cultures (CEC) were incubated in an anaerobiosis jar containing an anaerobic system (Anaerobac system - Probac do Brasil Ltda). These cultures were tested for the presence of Salmonella spp. using XLT4 agar.
The bacterial cultures were centrifuged at $12,000 \mathrm{x} \mathrm{g}$ for 30 min at $4^{\circ} \mathrm{C}$. After that the pellet was suspended in PBS $0.1 \mathrm{M}$ (pH 7.4) supplemented with glycerol $30 \%$. According to the pellet volume, the bacterial cultures were diluted 1:10. The bacterial suspension was frozen at $-20^{\circ} \mathrm{C}$ for $24 \mathrm{~h}$, and afterward was kept at $-80^{\circ} \mathrm{C}$ until the experimental study.

Three experimental frozen cultures were obtained: CE-A derived from the whole cecal contents with a mixture of aerobic and anaerobic bacterial cultures; CE-B containing aerobic bacterial cultures, and CE-C containing anaerobic bacterial cultures.

\section{Experimental protocol}

Day-old chicks were divided into five groups of 30 birds. Three CE experimental cultures were suspended 1:100 in PBS $0.1 \mathrm{M}(\mathrm{pH}$ 7.4) and giving to the chicks into the crop, three replicated groups of chicks per treatment. $24 \mathrm{~h}$ later, all chicks except those in the negative control group were challenged with SK into the crop with $0.1 \mathrm{~mL}$ of a cell suspension containing $3.6 \times 10^{6} \mathrm{CFU} / \mathrm{mL}(21)$.

On the fifth day after challenge the chicks were killed by cervical dislocation and the cecal contents were examined for Salmonella colonization from all treatments. After opening the ceca were aseptically removed and mixed with $9 \mathrm{~mL}$ of $1 \%$ peptone water into sterile plastic bags, and tenfold dilution was prepared for surface plating on XLT4 agar containing $20 \mu \mathrm{g} / \mathrm{mL}$ nalidixic-acid. The volume of inoculum required was $0.1 \mathrm{~mL}$ for each sample of cecal suspension (21). The plates were incubated for $24 \mathrm{~h}$ at $37^{\circ} \mathrm{C}$, and the number of colony- forming unit (CFU) of Salmonella Kedougou $\mathrm{Nal}^{\mathrm{R}}(20 \mu \mathrm{g} / \mathrm{mL})$ per gram of cecal content was calculated (21).

\section{Statistical analysis}

Viable counts were converted into logarithmic form and analysed using non-parametric tests. Data were assessed using Kruskall-Wallis test, Mann-Whitney test and Spearman correlation (30), as appropriate.

The efficacy of treatment cultures in protecting chicks against Salmonella infection was expressed using: a) number of chicks with different levels of Salmonella per $\mathrm{g}$ of cecal content; b) percentage of birds with infection; c) Infection Factor (IF) and Protection Factor (PF). IF is the logarithmic number colony forming units of Salmonella organism per gram $\left(\mathrm{IF}=\log 10 \mathrm{CFU} / \mathrm{g}^{-1}\right)$ of cecal contents and $\mathrm{PF}$ is the value obtained by dividing the control group IF by that IF from the treated group (21).

\section{RESULTS}

The results of the trials are shown in Tables 1 and 2. The three experimental treatments were shown to be effective in controlling Salmonella colonization. Treatment 1 (CE-A) caused 
a significant reduction of SK colonization when compared to the other two treated groups (Table 1). Treatments 2 (CE-B) and 3 (CE-C) resulted in significant reduction in colonization when compared to the control group - T4 (Table 1).

Results obtained from treated (CE-A, CE-B and CE-C) and untreated groups are presented in Table 2, where IF and PF were calculated according to Mead et al. (21). The IF value of 6.64 indicated strong colonization of cecum by SK in the control group, while in pre-treated chicks the IF values were between 0.41 and 1.22. PF values varied from 5.44 to 16.19 . The results of these trials were far below the limit of acceptance, and even below the value 4.0 that Mead et al. (21) suggested as a minimum for a treatment material to be effective against Salmonella in field conditions.

Non-treated controls, challenged with the same SK strain, IF of 6.64, demonstrating a strong colonization (Table 2). All groups

Table 1. Influence of treatment with experimental CE cultures on recovery of Salmonella Kedougou from ceca.

\begin{tabular}{lccccc}
\hline Treatment & \multicolumn{3}{c}{$\begin{array}{c}\text { Log10 Salmonella } \\
\text { UFC/g faeces }\end{array}$} & $\begin{array}{c}\text { Mean Log10 } \\
\text { Salmonella } \\
\text { UFC/g Faeces }\end{array}$ & $\begin{array}{c}\text { Positive } \\
\text { ceca }\end{array}$ \\
\hline Replication & 1 & 2 & 3 & & $(\%)$ \\
\hline T1 CE-A & 2.34 & 1.19 & 2.74 & $2.09^{\mathrm{a}}$ & 10.00 \\
& $(1 / 10)^{*}$ & $(1 / 10)$ & $(1 / 10)$ & & \\
T2 CE-B & 3.15 & 2.36 & 2.63 & $2.71^{\mathrm{b}}$ & 23.33 \\
& $(2 / 10)$ & $(3 / 10)$ & $(2 / 10)$ & & \\
T3 CE-C & 2.56 & 2.16 & 2.44 & $2.39^{\mathrm{c}}$ & 20.00 \\
& $(2 / 10)$ & $(2 / 10)$ & $(2 / 10)$ & & \\
T4 positive & 2.57 & 2.06 & 2.35 & 2.33 & 63.33 \\
control & $(6 / 10)$ & $(7 / 10$ & $(6 / 10)$ & & \\
\hline
\end{tabular}

$\mathrm{a}, \mathrm{b}, \mathrm{c}=$ no common superscript differ significantly $(\mathrm{p}<0.05)$.

$*$ (positive chicks/number of chicks challenged). showed values higher than four, but the best results were obtained in chicks treated with experimental frozen cultures containing a bacterial mixture produced under aerobic and anaerobic conditions (CE-A). In this case the PF was 16.19, which represents a considerable increase of protection it compared to the other groups. Chicks treated with experimental frozen cultures containing aerobic (CEB) or anaerobic (CE-C) bacteria, showed PF of 5.44 and 6.64, respectively.

Results for the different treated groups showed significant differences among them $(\mathrm{p}<0.05)$. A positive correlation between treatment and reduction of SK recovery was observed. Protection was demonstrated in all treated groups and varied from $76.66 \%$ to $90 \%$.

\section{DISCUSSION}

Different methods may be used to increase resistance against Salmonella infections (24). CE treatment is used to prevent Salmonella colonization. Oral administration of defined mixtures of bacterial isolates from faecal and cecal contents of adult chickens protect young chicks against infection with Salmonella. Defined bacterial mixtures give protection comparable to that of faecal or cecal cultures of unknown bacterial composition (31).

Our results showed that aerobic bacterial mixture protected chicks against $\mathrm{SK}$ colonization $(\mathrm{IF}=1.22, \mathrm{PF}=5.44)$, different from results obtained by Snoeyenbos et al., (29). Nevertheless, the experimental aerobic culture used in this trial had Lactobacillus $s p$, in its composition (data not published), a bacteria with proven capability to prevent growth of Salmonella in the cecum of chickens (19). The mechanisms of the protective effect are unknown. However, this protective effect could be due to antibacterial factors produced by Lactobacillus sp $(25,36)$, or to enhancement of the intestinal immunity (23).

Table 2. Data for control and treated chicks related to Infection Factor (IF) and Protection Factor (PF).

\begin{tabular}{|c|c|c|c|c|c|c|c|c|}
\hline \multirow{2}{*}{ Treatments } & \multicolumn{6}{|c|}{ Number of chicks infected } & \multirow[b]{2}{*}{ Infection Factor (IF) } & \multirow[b]{2}{*}{ Protection Factor (PF) } \\
\hline & 0 & 1 & 2 & 3 & 4 & $\begin{array}{l}* \\
\end{array}$ & & \\
\hline T1 CE-A & 27 & 0 & 0 & 1 & 2 & 0 & $(27 \times 0)+(1 \times 3)+(2 \times 4)=11 / 27=0.41$ & $\begin{array}{c}6.64 / 0.41=16.19 \\
90 \% \\
6.64 / 1.22=5.44\end{array}$ \\
\hline T2 CE-B & 23 & 0 & 0 & 1 & 5 & 1 & $(23 \times 0)+(1 \times 3)+(5 \times 4)+(1 \times 5)=28 / 23=1.22$ & $\begin{array}{c}76.66 \% \\
6.64 / 1=6.64\end{array}$ \\
\hline T3 CE-C & 24 & 0 & 0 & 1 & 4 & 1 & $(24 \times 0)+(1 \times 3)+(4 \times 4)+(1 \times 5)=24 / 24=1$ & $\begin{array}{c}80 \% \\
6.64 / 6.64=1\end{array}$ \\
\hline T4 Positive control & 11 & 0 & 0 & 4 & 14 & 1 & $(11 \times 0)+(4 \times 3)+(14 \times 4)+(1 \times 5)=73 / 11=6.64$ & $\begin{array}{c}36.66 \% \\
6.64 / 0=0\end{array}$ \\
\hline T5 Negative control & 30 & 0 & 0 & 0 & 0 & 0 & $(30 \times 0)=0 / 30=0$ & $100 \%$ \\
\hline
\end{tabular}

* These represent the Salmonella CFU/Log 10. 
The efficacy of CE was demonstrated in the group treated with anaerobic culture, with $80 \%$ of protection and a reduction of Salmonella colonization, which is similar to results obtained by Snoeyenbos et al. (29), Barnes et al. (2) and Schneitz et al. (26). Some mechanisms could explain this protective effect. Following CE treatment, the factors involved in protecting recipient birds against Salmonella are likely to be the same as those affecting the normal, adult microbiota. These mechanisms have recently been reviewed by Schneitz and Hakkinen (27). They include: a) creation of a restrictive physiological environment, involving microbial production of volatile fatty acids and a low oxidation-reduction potential; b) competition among different microbes for receptor sites; c) production of antibiotic-like substances, such as bacteriocins, by some microorganisms and d) microbial competition for essential nutrients. It seems unlikely that any single mechanism is wholly responsible for the protective effect of $\mathrm{CE}$ treatment.

The CE treatment with an experimental culture containing undefined aerobic and anaerobic cultures resulted in $\mathrm{IF}=0.41$ and $\mathrm{PF}=16.19$, similar to those obtained by Stavric (33), with a protective effect of $90 \%$ and a reduced SK colonization (10\%). It seems that successful protection against Salmonella colonization requires complex bacterial mixtures (34). However, protection is similar in defined and undefined complex mixtures $(15,17,27)$. According to Mead et al. (21) this treatment was more effective because it has a higher value of PF, similar to those obtained by Stavric et al. (31).

Present CE products are essentially undefined in composition, but contain a complex mixture of viable bacteria, some of which may play a part in the development of colonization resistance. The mechanisms of the protective effect are unknown, and may never be determined because of the complexity of the intestinal environment and the interactions between host and microbes that can occur (4).

The intestinal environment has indigenous microbes that modulate the immune response by increasing or decreasing the amounts of mediators secreted by immunocompetent cells $(4,10,11,37)$. The microbiota also provides a substantial amount of antigenic material for the mucosal immune system and can influence the oral immune response $(13,35)$.

Related to the host, genetic control of disease resistance is highly complex and can involve any of the body's defense systems and their interaction (9). It is well established that the responses of chickens to disease agents may vary. Differences in susceptibility among poultry breeds are attributable to varying genetic resistance and it has been shown that resistance of chicks to $S$. Typhimurium is linked to a dominant autosomal gene (7). Thus, different breeds of poultry respond differently to a standard Salmonella challenge. With some strains, mortality is high (97\% or more) while in others it is no more than $3 \%$. These observations are consistent and reproducible, suggesting that resistance is genetically determined and the situation for disease in the chick (18) is the same as that for resistance to cecal colonization by Salmonella (5). Among different breeds of chicken, variations have been reported in resistance to infection by $S$. Pullorum $(8,16), S$. Gallinarum $(8,28)$ and $S$. Enteritidis $(8,12)$.

Since there are many factors in the chick that could affect the microbiota and their interactions, mechanisms associated with host genetic resistance, microbial interaction on the intestinal environment, intestinal immunity, and others, can play an important role in the protective effect of CE products. The obtention of protection against Salmonella colonization is a complex process. While differences exist between animal species in the operation of the immune system, genetic resistance and others, they are functionally very similar. Information on the topic from any source can be used for further understanding the $\mathrm{CE}$ mechanism to protective effect.

\section{ACKNOWLEDGEMENTS}

The authors would like to thank FAPESP (grant n ${ }^{\circ}$ 97/127976) for financial support and CAPES for fellowship to L. Revolledo.

\section{RESUMO}

\section{Comparação de culturas experimentais de exclusão competitiva para o controle da colonização de Salmonella em pintos de corte}

Esse estudo avaliou a eficácia de três diferentes tipos de culturas de exclusão competitiva (EC-A, EC-B e EC-C) contra Salmonella Kedougou (SK), amostra NCTC 12173, resistente ao ácido Nalidíxico $\left(\mathrm{Nal}^{\mathrm{R}}\right)$, em pintos de um dia de idade, utilizando-se 4 tratamentos, em três repetições. A média logarítmica de Salmonella por gramas de fezes foi de 0,41 para o grupo tratado com a EC-A, contendo uma mistura de culturas bacterianas aeróbias e anaeróbias, derivada de conteúdo cecal de uma ave adulta; 1,22 no grupo tratado com a EC-B, contendo culturas bacterianas aeróbias; 1,00 no grupo tratado com a ECC, contendo culturas bacterianas anaeróbias e 6,64 no grupo controle positivo. A porcentagem de aves colonizadas variou de 10 a $23,33 \%$ nos grupos tratados e foi de $63,33 \%$ no grupo controle. Uma boa proteção (76,66 a 90\%) foi obtida em todos os tratamentos, sendo que a menor proteção foi verificada com os produtos experimentais contendo somente culturas de bactérias aeróbias ou anaeróbias. Os resultados sugerem que o uso de misturas de culturas aeróbias e anaeróbias pode ser efetivo para o uso na exclusão competitiva contra SK em frangos de corte.

Palavras-chave: Exclusão competitiva, Salmonella, frangos de corte. 


\section{REFERENCES}

1. Anderson, W.R.; Mitchell, W.R.; Barnum, D.A.; Julian, R.J. Practical aspects of competitive exclusion for the control of Salmonella in turkeys. Avian Dis., 28:1071-1078, 1984.

2. Barnes, E.M.; Impey, C.S.; Stevens, B.J.H. Factors affecting the incidence and anti-Salmonella activity of the anaerobic caecal flora of the young chick. J. Hyg., 82:263-283, 1979.

3. Bailey, J.S.; Stern, N.J.; Cox, N.A. Commercial field trial evaluation of mucosal starter culture to reduce Salmonella incidence in processing broiler carcasses. J. Food Protect., 63:867-870, 2000.

4. Berg, R.D. Indigenous intestinal microflora and host immune response. EOS J. Immunol Immunopharmacol., 4:161-168, 1985.

5. Berthelot, F.; Beaumont, C.; Mompart, F.; Girard-Santosuosso, O.; Pardon, P.; Duchet-Suchaux, M. Estimated heritability of the resistance to cecal carrier state of Salmonella enteritidis in chickens. Poult. Sci., 77:797-801, 1998.

6. Blankenship, L.C.; Bailey, J.S.; Cox, N.A.; Stern, N.J.; Brewer, R; Williams, O. Two-step mucosal competitive exclusion flora treatment to diminish Salmonellae in commercial broiler chickens. Poult. Sci., 72:1667-1672, 1993.

7. Bumstead, N.; Barrow, P. Genetics of resistance to Salmonella typhimurium in newly hatched chicks. Br. Poult. Sci., 29:521-529, 1988.

8. Bumstead, N.; Barrow, P. Resistance to Salmonella gallinarum, $S$. pullorum, and S. enteritidis in inbred lines of chickens. Avian Dis., 37:189-193, 1993.

9. Cooper, G.L. Salmonellosis-infections in man and the chicken: pathogenesis and the development of live vaccines- a review. Vet. Bull., 64:123-143, 1994.

10. De Simone, C. Microflora, yogurt and the immune system. Int. J. Immunother., Suppl. 11:19-23, 1986.

11. De Simone, C.; Ferrazzi, M.; Di Seri, M.; Baldinelli, L.; Di Fabio, S. The immunoregulation of the intestinal flora: bifidobacteria and lactobacilli modulate the production of g-interferon induced by pathogenic bacteria. Int. J. Immunother, 3:151-158, 1987.

12. Duchet-Suchaux, M.; Mompart, F.; Berthelot, F.; Beaumont, C.; Lechopier, P.; Pardon, P. Differences in frequency, ;level, and duration of cecal carriage between four outbred chicken lines infected orally with Salmonella enteritidis. Avian Dis., 41:559-567, 1997.

13. Faria, A.M.; Weiner, H.L. Oral tolerance: mechanisms and therapeutic applications. Adv. Immunol., 73:153-264, 1999.

14. Ferreira, A.J.P.; Ferreira, C.S.A.; Knöbl, T.; Moreno, A.M.; Baccaro, M.R.; Chen, M.; Robach, M., Mead, G.C. Comparison of three commercial competitive-exclusion products for controlling Salmonella colonization of broilers in Brazil. J. Food Protect., 66:490-492, 2003.

15. Gleeson, T.M.; Stavric, S.; Blanchfield, B. Protection of chicks against Salmonella infection with a mixture of pure cultures of intestinal bacteria. Avian Dis., 33:636-642, 1989.

16. Hutt, F.B.; Scholes, J.C. Genetics of the fowl XIII: breed differences in susceptibility to Salmonella pullorum. Poult. Sci., 20:342-352, 1941.

17. Impey, C.S.; Mead, G.C.; George, S. Competitive exclusion of salmonellas from the chick caecum using a define mixture of bactterial isolates from the cecal microflora of an adult bird. J. Hyg., 89:479490, 1982.
18. Lambert, W.C. Natural resistance to disease in the chick. III. The comparative resistance of different breeds. J. Immunol., 23:253260, 1932.

19. Massa, S.; Sarra, P.G.; Canganella, F.; Trovatelli, L.D. Protection of young chicks against Salmonella kedougou by administration of intestinal microflora. Int. J. Food Microbiol., 40:123-126, 1998.

20. Mead, G.C. Prospects for competitive exclusion treatment to control salmonellas and other foodborne pathogens in poultry. Vet. J., 159:111-123, 2000

21. Mead, G.C.; Barrow, P.A.; Hinton, M.H.; Humbert, F.; Impey, C.S.; Lahellec, C.; Mulder, R.W.A.; Stavric, S.; Stern, N.J. Recommended assay for treatment of chicks to prevent Salmonella colonization by competitive exclusion. J. Food Protect., 52:500-502, 1989.

22. Nurmi, L.; Rantala, M. New aspects of Salmonella infection in broiler production. Nature, 241:210, 1973.

23. Perdigon, G.; Alvarez, S.; De Macias, M.E.N.; Roux, M.E.; Holgado, A.P.R. The oral administration of lactic acid bacteria increase the mucosal intestinal immunity in response to enteropathogens. $J$. Food Protect., 53:404-410, 1990.

24. Saeed, A.M.; Gast, R.K.; Potter, M.E.; Wall, P.G. Salmonella enterica serovar Enteritidis in human and animals. Iowa State University Press, Ames, 1999. 443p.

25. Sarra, P.G.; Dellagio, F.; Botazzi, B. Taxonomy of lactobacilli isolated from the alimentary tract of chickens. Appl. Microbiol., 6:86-89, 1985.

26. Schneitz, C.; Seuna, E.; Rizzo, A. The anaerobically cultures cecal flora of adult fowls that protects chickens from Salmonella infections. Acta Pathol. Microbiol., Scan. B, 89:109-116, 1981.

27. Schneitz, C.; Hakkinen, M. Comparison of two different types of competitive exclusion products. Lett. Appl. Microbiol., 26:338-341, 1998.

28. Smith, H.W. The susceptibility of differents breeds of chickens to experimental Salmonella gallinarum infection. Br. Poult. Sci., 35:701-705, 1956

29. Snoeyenbos, G.H.; Weinack, O.M.; Smyser, C.F. Protecting chicks and poults from Salmonellae by oral administration of normal gut microflora. Avian Dis., 22:273-287, 1978.

30. Spiegel, M. Estatística. Makron Books do Brasil, São Paulo, 1994, $643 \mathrm{p}$.

31. Stavric, S.; Gleeson, T.M.; Blanchfield, B.; Pivnick, H. Competitive exclusion of Salmonella from newly hatched chicks by mixtures of pure bacterial cultures isolated from cecal and cecal contents of adult birds. J. Food Protect., 48:778-782, 1985.

32. Stavric, S. Microbial colonization control of chicken intestine using defined cultures. Food Technol., 41:93-98, 1987.

33. Stavric, S. Defined cultures and prospects. Int. J. Food Microbiol., 15:245-263, 1992.

34. Stavric, S.; D'Aoust, J.Y. Undefined and defined bacterial preparation for the competitive exclusion of Salmonella in poultry-a review. $J$. Food Protect., 56:173-180, 1993.

35. Strober, W.; Kelsall, B.; Marth, T. Oral tolerance. J. Clin. Immunol., 18:1-30, 1998 .

36. Talarico, T.L.; Dobrogosz, W.J. Purification and characteriztion of glyceroldehydratase from Lactobacillus reuteri. Appl. Environm. Microbiol., 56:1195-1197, 1990.

37. Weir, D.M.; Blackwell, C.C. Interaction of bacteria with the immune system. J. Clin. Immunol., 10:1-2, 1983. 